\title{
PAAUGLIŲ RIZIKINGO ELGESIO INTERNETE VEIKSNIAI
}

\author{
Rasa Jokubaitė \\ Klaipédos universitetas
}

\begin{abstract}
Anotacija
Straipsnyje analizuojami veiksniai, didinantys ir mažinantys rizikingo elgesio raišką internete. Skiriami vidiniai ir aplinkos veiksniai, skatinantys tokị elgesį. Vidiniai veiksniai struktūruojami individualiu lygmeniu, kuriame skiriama amžiaus ypatumų, asmenybės savybių ir elgesio problemų reikšmé rizikingo elgesio raiškai internete. Aplinkos įtaka - taip pat svarbus veiksnys paauglio rizikingam elgesiui internete. Aplinkos veiksniai struktūruojami šeimos, bendraamžių, mokyklos lygmenimis. Šeimos santykiu kokybė, šeimos sudètis, materialinė padètis gali tapti rizikingo elgesio internete veiksniu. Reikšmingą vaidmeni paauglystėje atlieka neigiama bendraamžių ịtaka, patiriama socialinè atskirtis gali būti susijusi su paauglių polinkiu į rizikingą veiklą internete. Psichologiniai ir socialiniai mokyklos aspektai, akademiniai rezultatai, savirealizacijos galimybės mokyklos veikloje išskiriami kaip tokio elgesio veiksniai. Paauglių rizikingo elgesio internete veiksnių analizè atskleidè, kad svarbu ieškoti teoriškai pagrịstų ir praktiškai patikrintų paauglių saugumą virtualioje erdvejje užtikrinančių būdų.

PAGRINDINIAI ŽODŽIAI: paaugliai, rizikingas elgesys internete, elgesio veiksniai.
\end{abstract}

\begin{abstract}
Today's technological advance and rapid development provide teenagers with a lot of opportunities for learning, free time and self-expression. Main factors encouraging teenagers' risky behavior online are distinguished into internal and environmental. Internal factors are structured in accordance to the individual level, which distinguishes the significance of age characteristics, personal features and behavior problems in regard to the expression of risky actions on the internet. Environmental influence is an important factor in point of risky actions of teenagers on the internet as well. Environmental factors are structured into the levels of family, peers and school. Quality of family relations, family context and circumstance may become a factor of risky behavior online. Negative influence of peers plays a significant role during the adolescence. Social isolation experienced among peers may have coherence with teenagers' tendency to the risky behavior online. Psychological and social school aspects, academic achievements and self-realization opportunities through school work are also distinguished as factors of such behavior. Analysis of teenagers' risky behavior online showed that it is important to look for theoretically grounded and practically checked ways of ensuring teenagers' safety in virtual reality.

KEY WORDS: teenagers, risky behavior online, factors of behavior.
\end{abstract}

\section{Ivadas}

Šiandien jaunimo kasdieniame gyvenime internetas užima svarbią vietą. Tarptautinių tyrimų rezultatai atskleidžia paauglių naudojimosi internetu didejjimo tendenciją: 93 \% 9-16 metų amžiaus vaikų naudojasi internetu ne rečiau kaip kartą per savaitę, 60 \% internete naršo beveik kiekvieną dieną (Livingstone ir kt., 2011). Lietuvoje paaugliai internetu naudojasi dažniau nei Europoje. Net 95 \% šešioli- 
kmečiu mūsų šalyje naudojasi internetu ne rečiau kaip kartą per savaitę, aktyviai bendrauja interneto socialiniuose tinkluose, daugelis turi savo asmenini socialini profili. Nustatyta, kad 59\% 9-16 metų amžiaus vaikų turi bent vieną profili socialiniuose tinkluose (iš jų 26 \% - 9-10 metų ir 82 \%-15-16 metų amžiaus). Pažymima, kad tik Olandijoje vaikų, turinčių socialinị profili, skaičius yra šiek tiek didesnis ( $80 \%$ ) nei Lietuvoje (76 \%). Vaikai, paaugliai užsiima ịvairia internetine veikla: dominuoja internetiniai žaidimai, informacijos paieška, vaizdo peržiūros, internetiniai dienoraščiai, dalyvavimas socialiniuose tinkluose ir kt. (EU Kids Online, 2010). Lietuvoje atliktų tyrimų duomenimis, svarbiausios paauglių veiklos internete yra naršymas informaciniuose pažintiniuose tinklalapiuose, vaizdo ir kitos medžiagos mainai, peržiūra, klausymasis ir dalyvavimas internetiniuose socialiniuose tinkluose (Žibènienè, Brasienè, 2013).

Svarbus tiriamos problemos aspektas - internetinès veiklos ir ịvairių rizikų ryšys. 2010 m. atliktame tyrime „Europos vaikai internete II“ teigiama, kad Lietuvoje gana aukštas naudojimosi internetu lygis, todèl ir rizika vaikams čia yra didesnè nei šalyse, kuriose naudojimosi internetu lygis yra žemesnis (EU Kids Online II, 2010). Pastaruoju metu daug diskutuojama apie paauglių gerovei kenkiančias interneto grèsmes. Paauglystejje intensyviai vyksta asmens savo tapatumo paieškos, iš vaikystės pereinama ị suaugusiojo pasauli, todèl paaugliai neretai puola ị kraštutinumus, jiems dažnai kyla ịvairių prieštaravimų, noras rizikuoti (Dowell, Burgess, Cavanaugh, 2009). Šiame amžiaus tarpsnyje dar tvirtai nesusiformavę gebejjimai kritiškai vertinti supančią aplinką, todèl atsparumo grèsmėms atžvilgiu paaugliai yra gana pažeidžiami (Zaleckienè, 2003).

Klausimo problemiškumą atskleidžia tai, kad paauglių elgesys internetinèje erdvejje kinta, jis tampa vis rizikingesnis. Paaugliai dažnai kontaktuoja su nepažistamaisiais, naudojasi smurtinio ir seksualinio turinio interneto svetainėmis, populiarèja paaugliu elektroninès patyčios (EU Kids Online II, 2010; Ruškus, Žvirdauskas, Kačenauskaite, 2009; Pilkauskaitè-Valickienė, Raižienė, Žukauskienė, 2009). Priekabiavimas ir nepageidaujami seksualinio turinio pranešimai, asmeninès informacijos skelbimas, patyčios, asmens tapatybès vagystès ir kt. dažnai lemia paauglių pažeidžiamumą (Christofides, Muise, Desmarais, 2012; Barbovski, Marinescu, Velicu, 2011; Livingstone, 2008). Paauglių pažeidžiamumas internetinejje erdvejje skiriasi lyties aspektu. Paaugliai, ypač mergaitès, labiau linkusios issitraukti į veiklą interneto socialiniuose tinkluose (Lenhart, 2009; Ruškus, Žvirdauskas, Kačenauskaite ir kt., 2009), tuo tarpu berniukai labiau linkę issitraukti i kompiuterinius žaidimus, azartinius lošimus, vaizdo prieigas turinčias svetaines (Lenhart, 2009).

Nagrinėjamos problemos aktualumą atskleidžia ir veiksniai, turintys įtakos rizikingam paauglių elgesiui internete. Paaugliai, kurie yra mažiau patenkinti savo 
gyvenimu, naudoja internetą kaip bendravimo aplinką, kurioje jaučiasi labiau savimi pasitikintys, ypač akcentuojant anoniminio bendravimo galimybes (Pociūtè, Krancaitè, 2012; Livingstone, Helsper, 2008). Paaugliai, kurių santykiai su tėvais, bendraamžiais nėra tvirti, tikètina, dažniau ieškos bendravimo galimybių internete (Christofides, Muise, Desmarais, 2012). Pastarieji internetą vertina kaip palankią galimybę užmegzti asmeninius ir intymius ryšius su kitais asmenimis (Livingstone, Helsper, 2008). Paauglių rizikingo elgesio internete problema skatina domètis rizikos ir apsauginiais veiksniais, kurie turi itakos tokio elgesio raiškai internete.

Rizikingas elgesys internete neigiamai veikia paauglio socialinio gyvenimo kokybę, jo fizinę ir psichinę sveikatą (Livingstone ir kt., 2011). Naudojimasis internetu be jokių apribojimų ar kontrolès dažniausiai lemia neigiamus padarinius paauglio socializacijai (Noll, Chad, Barnes, 2013; Christofides, Muise, Desmarais, 2012).

Analizuojant paauglių elgesio internete problemas daug dèmesio skiriama paauglių elgesiui socialiniuose tinkluose (Christofides Muise, Desmarais, 2012; Kolpakova, Liubimova, Levina, 2012; Guan, Subrahmanyam, 2009; Lenhart, 2009; Livingstone, Helsper, 2008).

Lietuvos mokslininkų (Bulotaitè, 2009; Lekavičienè ir kt., 2010; Ruškus, Žvirdauskas, Kačenauskaite, 2009) atliktais tyrimais nustatyta, kad mūsų šalies paaugliams trūksta žinių ir gebejjimų, kurie būtini, norint apsisaugoti nuo grèsmių internete, pabrezžiama paauglių švietimo plètojimo, jų psichologinio ir socialinio atsparumo didinimo būtinybè. Lietuvoje rizikingo elgesio internete temos problemiškumas aptariamas psichologijos mokslo kontekste, tiriant paauglių aktyvumo internete ir asmenybès bruožų sąsajas, priklausomybę nuo interneto, nagrinejjant jo poveiki asmenybei, elektroniniu patyčiu paplitimą (Pociūtė, Krancaite, 2012; Lekavičienė, Vasiliauskaite, Antinienė, Almonaitienė, 2010; Bulotaitè, 2009; Pilkauskaitè-Valickienė, Raižienė, Žukauskienė, 2009).

Edukologijos mokslo atstovai tiria paauglių elgesio internete problemą šiais aspektais: paauglių vaikinų įsitraukimas į internetinę pornografiją ir jų sąmoningumo ugdymas (Ruškus, Sujeta, 2011), paauglių naudojimasis internetu ir internetiniais socialiniais tinklais bei patiriamos grèsmès juose (Žibènienė, Brasienė, 2013), paauglių elgsena elektroninėje erdvèje (Ruškus, Žvirdauskas, Kačenauskaitė ir kt., 2009). Mokslinių darbų (Pociūtè, Krancaitė, 2012; Ruškus, Sujeta, 2011; Ruškus, Žvirdauskas, Kačenauskaitè ir kt., 2009) analizė rodo, kad trūksta tyrimų, kurie atskleistų, kaip paaugliams padèti ịveikti grẻsmes, kylančias virtualioje erdvejje. Tačiau, siekiant atrasti paauglių rizikingo elgesio įveikos būdų, teorinès analizès pagrindu pirmiausia būtina atskleisti paauglių rizikingą elgesị lemiančius veiksnius. 
Todèl šio tyrimo mokslinè problema formuluojama klausimu: kokie veiksniai lemia paauglių rizikingą elgesi internete?

Tyrimo objektas: paauglių rizikingo elgesio internete veiksniai.

Tyrimo tikslas - susisteminti ir aprašyti paauglių rizikingo elgesio internete veiksnius.

Tyrimo metodai: mokslinès literatūros analize, leidusi analizuoti ir sisteminti mokslinius tyrimus nagrinejjama tema; lyginamoji analizè, sudariusi galimybes palyginti i̇vairių autorių idejas ir mokslinių tyrimų rezultatus, atskleidžiant paauglių rizikingo elgesio internete veiksnius.

\section{Paauglių rizikingo elgesio internete veiksnių struktūra}

R. Jessor (1991) rizikingą elgesị apibūdina kaip socialiai nepriimtiną, neatitinkantị visuotinai pripažintų taisyklių. Toks elgesys dažniausiai siejamas su lytinèmis rizikomis, ivvairiomis priklausomybių formomis. Rizikingas elgesys aiškinamas remiantis probleminio elgesio teorija, kurioje probleminè elgsena apibrěžiama kaip individo elgesio ir jo aplinkos sąveikos rezultatas (Jessor, 1991). E. Dowell, A. Burgess, D. J. Cavanaugh (2009) teigimu, spartus naujų technologijų tobulejjimas šiandien lèmé naują rizikingo elgesio formą - rizikingą elgesị internete.

Ši problema vis dažniau tampa mokslinių diskusijų objektu, tačiau teoriniame lygmenyje visuminė rizikingo elgesio internete samprata neatskleista, išryškinti tik kai kurie tokio elgesio aspektai. Išanalizavus ir apibendrinus mokslinius tyrimus, rizikingą elgesị internete galima apibrèžti kaip potencialiai pavojingus veiksmus virtualioje erdveje, kurie sukelia grèsmes / rizikas interneto vartotojui (Milne, Lauren ir kt., 2009; Berson, Berson, 2005). Apibūdinant paauglių pažeidžiamumą internete, plačiai vartojama kita - viktimizacijos naudojant internetq sąvoka, kuri reiškia, kad interneto vartotojas tampa interneto auka, patiria jo keliamas grèsmes, kurios turi žalingų pasekmių (Ruškus, Žvirdauskas, Kačenauskaite, 2009).

Asmens rizikingam elgesiui internete gali turèti itakos kai kurie veiksniai. R. Jessor (1991) probleminio elgesio teorijoje apibrèžia, kad rizikos veiksnys - tai kiekvienas poveikis ar įtaka, didinantys tikimybę, kad gali kilti nauja problema arba padidèti jau egzistuojanti. Rizikos veiksniai gali ne tik suformuoti prielaidas problemai atsirasti, bet ir gali ją palaikyti arba paskatinti toliau progresuoti. Pašalinus ,asmenybės deficitą", noras rizikingai elgtis turètų sumažèti (Jessor, 1991). Taigi norint išskirti paauglių rizikingą elgesį internete lemiančius veiksnius, reikia j̇vardinti du aspektus: tokị elgesi skatinančius ir nuo jo apsaugančius veiksnius.

Siekiant susisteminti ir aprašyti paauglių rizikingą elgesị internete skatinančius ir nuo jo apsaugančius veiksnius, išryškinti vidiniai bei aplinkos veiksniai. Vidiniai 
veiksniai nagrinėjami individualiu lygmeniu, aplinkos - šeimos, bendraamžių bei mokyklos lygmenimis.

Individualiame lygmenyje skiriami šie paauglių rizikingą elgesị internete skatinantys veiksniai: paauglystės amžiaus tarpsnis, jo ypatumai; asmenybės savybès, elgesio problemos. R. Žukauskienè (2012) akcentuoja, kad paauglystejje gerokai padažnėja rizikingo ir neatsargaus elgesio atvejų, ryškus aštrių pojūčių siekis, šiame amžiaus tarpsnyje paaugliai dažniau renkasi padrika, permainingą ir emocijoms paklūstantị elgesị. Atlikto tyrimo EU Kids Online (2010) duomenimis, vaikų susidūrimas su rizikomis internete dažnis taip pat siejamas su jų amžiumi: $14 \%$ 9-10 metų vaikų yra patyrę vieną ar daugiau riziku, 11-12 metų vaikų grupejje rizikų skaičius išaugo iki 33\%, 13-14 metu grupejje - $49 \%$ ir 15-16 metu grupejje - atitinkamai $63 \%$ rizikų. Vyresni paaugliai labiau nei jaunesni vaikai domisi įvairia komunikacine veikla internete, todèl jie dažniau gali susidurti su rizikingu bendravimu virtualioje erdvejje (Noll, Chad, Barnes, 2013). R. Lekavičienė, Z. Vasiliauskaitè, D. Antinienè, J. Almonaitienè (2010) pabrèžia, kad aktyviausi virtualaus bendravimo dalyviai yra paaugliai ir jaunimas iki 25 metu.

B. Pociūtès, E. Krancaitès (2012) paauglių grupèse atlikti tyrimai atskleidè, kad paauglių asmens savybės siejasi su jų elgsena socialiniuose tinkluose. Paaugliu, pateikiančių daug asmeninès informacijos apie save, linkusių tinkle „draugauti“" su realiai nepažistamais asmenimis, atvirumo ir neurotiškumo bruožai yra stipriai išreikšti. Socialinio bendravimo kompensacijos požiūriu, paaugliai, kurių stipriai išreikštas neurotiškumo bruožas, linkę veikti socialiai pasyviu būdu. Ekstravertiškiems paaugliams neužtenka tik internetinio bendravimo, t. y. ekstravertai linkę realiai susitikti su žmonėmis, su kuriais susipažino tinkle. Paaugliai, kurie jaučiasi vieniši, yra labai įsitraukę i naudojimąsi socialiniais tinklais, čia skelbia daugiau asmeninès informacijos. B. Pociūtè, K. Krancaitè (2012), R. Lekavičienė, Z. Vasiliauskaitè, D. Antinienè, J. Almonaitienè (2010), O. Kolpakova, A. Liubimova, O. Levina (2012), S. Livinstone, E. Helsper (2008) pabrěžia interneto socialinių tinklų grèsmes paaugliams, kurie virtualią erdvę vertina kaip palankią galimybę užmegzti intymius ir asmeninius ryšius su kitais asmenimis. Virtualus bendravimas tampa labai svarbus, o dažnai - ir vienintelis tiems asmenims, kurie stokoja realių tarpasmeninių santykių arba turi bendravimo sunkumų. Paaugliai, kurie yra mažiau patenkinti savo gyvenimu, naudoja internetą kaip bendravimo aplinką, kurioje jie jaučiasi labiau pasitikintys savimi, ypač akcentuojant anoniminio bendravimo galimybes. Tokie paaugliai isitraukia į naudojimąsi socialiniais tinklais, nes bendraudami internete jie jaučiasi saugiau, nei ,akis i akị“. Internetinio bendravimo pranašumai šiuo atveju yra: anonimiškumas; galimybė ilgiau pamąstyti ir pakoreguoti tekstini pranešimą; labiau kontroliuojamas savęs pateikimas ir ispūdžio valdymas (Pociūtè, Krancaitè, 2012). 
Kitas aspektas, padedantis atskleisti vidinių veiksnių itaką paauglių rizikingam elgesiui internete, - tai elgesio problemos: perdètas savo asmenybès vertinimas, neigiamas požiūris į dorovines vertybes, asocialus elgesys (smurtas, patyčios), socialinių normų ir vertybių atmetimas, atitolimas nuo kitų, žema savigarba turi sąsajų su polinkiu rizikingai elgtis (Aramavičiūtè, 2005; Jessor, 1991).

Šiame lygmenyje išskiriami ir veiksniai, kurie apsaugo paauglius nuo rizikingo elgesio internete. Rizikingas elgesys, kaip ir bet kuris kitas išmoktas elgesys, yra funkcinis, siekiant tikslo (Jessor, 1991), todèl komunikabilumas, pasitikejjimas savimi, stipri moralinių vertybių sistema gali apsaugoti paauglius nuo pažeidžiamumo internete. B. Pociūtès, E. Krancaitès (2012) atlikti tyrimai atskleidè, kad paaugliai, kurių sąmoningumas stipriai išreikštas, mažiau linkę rizikingai elgtis internete.

R. Jessor (1991) teigimu, aplinkos veiksniai turi didesnę itaką rizikingo elgesio raiškai nei vidiniai. Individas yra socialinès aplinkos dalis, tad jos poveikis paauglio elgesiui taip pat ryškus. Kaip jau minèta, aplinkos poveikis rizikingam paaugliu elgesiui internete išskiriamas trimis lygmenimis: šeimos, bendraamžiu, mokyklos.

Šeimos lygmenyje išryškinamos trys veiksnių grupès, skatinančios rizikingo elgesio raišką internetinejje erdveje: šeimos psichologinè atmosfera, šeimos sudètis, materialinè padètis. Šeima yra pirminis socialinis veiksnys, turintis įtakos paauglio nuostatų ir elgesio formavimuisi. Naudojimosi internetu dažnis, trukmè ir patiriamos rizikos glaudžiai susiję su įvairiomis šeimos charakteristikomis. Pastebima, kad šeimos psichologinè atmosfera yra vienas pagrindinių rizikos veiksniu užsiimant pavojinga veikla internete. M. Wells, K. J. Mitchell (2008) paaugliu grupių atliktas tyrimas atskleidè, kad susvetimèjimas, emocinės šilumos trūkumas, konfliktai, bendravimo problemos šeimoje glaudžiai siejasi su paauglių isitraukimu iz interneto socialinius tinklus, dẻl ko paaugliai linkę dažniau užmegzti artimus santykius su asmenimis iš šių tinklų. Pažymima, kad paaugliai, kurie jaučiasi izoliuoti, nesuprasti, kuriems trūksta palaikymo, supratimo ir dèmesio šeimoje, naudodamiesi internetu gali būti labiau pažeidžiami. C. Greenhow, J. R. Walker, S. Kim (2009), S. K. Park, A. Y. Kim, C. B. Cho (2008), R. Wang, S. M. Brianchi, S. Raley (2005) tyrimai taip pat atskleidè, kad nepalanki šeimos psichologinė atmosfera, joje vyraujantis smurtas ir agresija, alkoholio ir narkotiku vartojimas, asocialių vertybių dominavimas, paauglio nepriežiūra, ịvairios auklejjimo klaidos skatina paauglių isitraukimą į rizikingą elgseną internete ir lemia neigiamas pasekmes. O. Kolpakova, A. Liubimova, O. Levina (2012), G. S. Mesch (2003) akcentuoja, kad ir šeimos sudètis turi itakos paauglio rizikingai veiklai internete. Tyrimai (Kolpakova, Liubimova, Levina, 2012; Mesch, 2003) atskleidè, kad pilnoje šeimoje tèvai gali daugiau dėmesio ir laiko skirti vaikų laisvalaikiui nei šeimose, kuriose 
nėra tėvo ar motinos. Yra didesnè tikimybė, kad nepilnose šeimose vaiku veiklos ir praleidžiamo laiko internete kontrolè gali būti mažesnè. Šeimos materialinė padètis taip pat gali tapti veiksniu, lemiančiu paauglių rizikingą veiklą internete. Šeimose, kur paaugliai turi asmeninį kompiuteri ir galimybę juo naudotis asmeniniame kambaryje / miegamajame, tèvai rečiau domisi paauglio veikla internete ir mažiau kontroliuoja jo elgesị virtualioje erdvèje. Tuo tarpu patys paaugliai jaučiasi savarankiškesni, drąsiau naudojasi internetu (Kolpakova ir kt., 2012).

Moksliniuose tyrimuose skiriami ir apsauginiai veiksniai šeimos lygmenyje, turintys ịtakos paauglių saugumui internetinejje erdvèje. C. Greenhow, J. R. Walker, S. Kim (2009), M. Wells, M. W. Mitchell (2008), S. K. Park, A. Y. Kim, C. B. Cho (2008), R. Wang, S. M. Brianchi, S. Raley (2005) akcentuoja, kad stabili, pilna šeima, tėvų domėjimasis paauglių veikla, jų palaikymas, tinkamas auklëjimas, taisyklių nustatymas gali padèti apsaugoti paauglius nuo grèsmių, daryti įtaką taigiamam vaiko elgesiui internete.

Paauglystėje ypač svarbūs yra bendraamžiai, todèl šiame lygmenyje skiriami veiksniai taip pat turi itakos paauglių pavojingai veiklai internete. Kaip skatinamuosius veiksnius galima išskirti: neigiamą bendraamžių įtaką bei socialinę izoliaciją tarp bendraamžių. Informacinès technologijos daro įtaką savitai paauglių elgesio kultūrai, todèl grupès poveikis paauglio rizikingam elgesiui internete taip pat svarbus. Paauglys siekia save išreikšti, atskleisti savo individualybę, o charakterio bruožai, leidžiantys tą individualybę atskleisti, dar tik formuojasi, todèl neretai bendraamžiai gali skatinti ịsitraukti i rizikingą veiklą internete (Umbrasienè, Narkauskaitè, 2010). Rizikingas paauglių elgesys iš dalies siejamas su tuo, kad jie daugiau laiko praleidžia su bendraamžiais (Brown, 2004) ir yra jautresni jų paskatoms, labiau siekia aštriu pojūčių, linkę rizikingai elgtis, labiau prisitaiko prie grupių, kurių nariais yra, atmeta tévų nustatytas ir labiau orientuojasi į bendraamžių pateikiamas elgesio normas, kurios dažnai yra skirtingos ir tas skirtumas skatina paauglius palankiau vertinti socialiai nepriimtiną elgesi (cit. Žukauskienè, 2012, p. 487). Internetinèje erdvèje paaugliai gali susidurti su ịvairiomis bendraamžiu grupèmis, todèl neretai gali tapti ịvairiu grèsmių internete aukomis ar būti ịtraukti į rizikingą veiklą internete kitų savo bendraamžių. Paauglių elgesio tyrimai atskleidžia, kad paaugliai, kurie dažniausiai yra izoliuoti, nesuprasti, nuvertinti, stokojantys visokeriopo bendraamžiu aplinkos palaikymo, internete yra linkę elgtis 2,5 karto rizikingiau (Eldeleklioglu, 2008).

R. Žukauskienė (2012) pastebi, kad bendraamžių palaikymas, pasitenkinimas tarpusavio ryšiais, pozityvios bendraamžiu savirealizacijos galimybės gali tapti veiksniais, kurie apsaugo nuo rizikingo elgesio, tad galima daryti prielaida, jog šie veiksniai taip pat gali mažinti paauglių rizikingo elgesio raišką internete. 
Moksliniai tyrimai atskleide, kad mokyklos lygmenyje taip pat išryškẻja veiksnių, kurie lemia rizikingo elgesio dinamiką paauglysteje (Kolpakova, Liubimova, Levina, 2012; Jessor, 1991). Mokyklos aplinka, socialiniai ryšiai, akademiniai pasiekimai bei saviraiškos galimybès gali turèti sąsajų su paauglių polinkiu į pavojingą veiklą internete. Nesaugi aplinka, prisitaikymo mokykloje sunkumai, socialinė atskirtis, patyčios mokykloje, silpni paaugliu emociniai ryšiai mokyklos aplinkoje (su pedagogais, bendraklasiais) turi ittakos paauglių paguodos paieškai internetinèje edrveje (Wells, 2006). O. Kolpakova, A. Liubimova, O. Levina (2012) kaip rizikingą elgesị internete skatinančius veiksnius išskiria mokyklos būklę, skurdžią, nesaugią šios ugdymo institucijos aplinką. Mokyklos, kuriose menkai šviečiama apie saugumą virtualioje erdveje, gali skatinti paaugliu rizikingą elgesį internete. Pastebima, kad menki akademiniai pasiekimai, saviraiškos galimybių trūkumas mokyklos veikloje taip pat turi itakos paauglių rizikingai elgsenai (Jessor, 1991).

Tuo tarpu mokyklos taisykliu pripažinimas, jų laikymasis, akademiniai ịsipareigojimai, prieraišumas gali tapti apsauginiais veiksniais, kurie mažintų paauglių rizikingo elgesio internete problemą. Akademiniai laimejjimai, savirealizacijos galimybės mokyklos veikloje, popamokinè veikla taip pat priskiriami prie rizikingą elgesị mažinančių veiksnių (Kolpakova, Liubimova, Levina, 2012).

Išanalizavus mokslinę literatūrą apie rizikingą elgesi internete lemiančius veiksnius, pastebèta, kad mūsų šalyje plačiau atskleidžiami rizikingo paauglių elgesio veiksniai, tačiau tokio elgesio veiksniams internete skiriama mažai dèmesio. Rizikingo elgesio internete sampratos atskleidimas, ši elgesị lemiančių veiksnių sisteminimas ypač svarbūs siekiant spręsti paauglių rizikingo elgesio internete problemą ir ieškant teoriškai pagrịstu bei praktiškai patikrintų paauglių saugumą virtualioje erdvejje užtikrinančių būdų.

\section{Išvados}

Pastaruoju metu paauglių elgesys internetinejje erdvejje kinta, jis tampa vis rizikingesnis. Rizikingas elgesys internete apibūdinamas kaip potencialiai pavojinga veikla virtualioje erdveje, kuri kelia grèsmę interneto vartotojui.

Paauglių rizikingo elgesio raiškai internete ịtakos turi tokị elgesị skatinantys ir nuo jo apsaugantys veiksniai. Susisteminus paauglių rizikingo elgesio internete veiksnius galima skirti vidinius ir aplinkos veiksnius, kurie lemia paauglių elgseną virtualioje erdvejje. Vidiniai veiksniai nagrinejjami individualiame lygmenyje, jie apima paauglystės amžiaus tarpsnio ypatumus, asmenybės bruožus ir elgesio problemas. Stipriai išreikšti atvirumas ir neurotiškumas, vienišumo jausmas, nepasitikẻjimas savimi, bendravimo sunkumai dažniau skatina paauglio poreikị rizikuoti internete. Asocialus elgesys, socialinių normų, vertybių atmetimas taip pat siejasi 
su polinkiu ị rizikingą elgesị internetinèje erdvèje. Aplinkos veiksniai struktūruojami šeimos, bendraamžių ir mokyklos lygmenyse. Šeimos lygmenyje skiriami šie aspektai: šeimos psichologinès problemos (konfliktai, smurtas, asocialus elgesys, nesaugumo jausmas), nepilna šeimos sudètis ir gera materialinè padètis. Paaugliai, jaučiantys bendraamžiu socialinę atskirti, nesuprasti, nuvertinti, stokojantys visokeriopo draugu palaikymo, tikètina, bus labiau linkę rizikingai elgtis internete. Bendraamžių neigiama ịtaka taip pat gali būti rizikingą elgesị internete skatinantis veiksnys. Mokyklos lygmuo apima šiuos veiksnius: nesaugi mokyklos aplinka, menki akademiniai laimèjimai, silpni mokinių ir pedagogų ryšiai, savirealizacijos galimybių trūkumas, švietimo apie saugumą internete stoka.

Paauglių rizikingą elgesį internete mažinantys vidiniai veiksniai apima: aukštą sąmoningumo lygi, stiprią vertybių sistemą, pasitikejjimą savimi, efektyvius komunikavimo igūdžius. Supratimas, palaikymas šeimoje, tinkamas auklejjimo stilius - tai aplinkos veiksniai, kurie gali mažinti paauglių pažeidžiamumą internete. Pozityvūs santykiai su draugais, bendraklasiais, savirealizacijos galimybės, aukšti akademiniai laimèjimai, saugumo jausmas mokykloje taip pat yra aplinkos apsauginiai veiksniai, užtikrinantys paauglių saugų elgesị internetinèje erdvejje.

Gauta 20131102

Pasirašyta spaudai 20140214

\section{Literatūra}

Aramavičiūtè, V. (2005). Auklëjimas ir dvasinè asmenybès branda. Vilnius: Gimtasis žodis.

Barbovski, M., Marinescu, V., Velicu, A. (2011). Being in contact with strangers: teenagers' exploration of alternative identities online. Revista de Asistenta Sociala, vol. 10, no. 2: 61-77.

Berson, I., Berson, M. (2005). Challenging Online Behaviors of Youth. Social Science Computer Review, vol. 23, no. 1: 29-38.

Bulotaitè, L. (2009). Priklausomybiu anatomija / narkotikai, alkoholis, lošimas, internetas, darbas, pirkimas. Vilnius: Tyto alba.

Christofides, E., Muise, A., Desmarais, S. (2012). Risky dislocures on facebook: the effect of having a bad experience on online behavior. Journal of adolescent research, vol. 27, no. 6: 714-728.

Dowdell, E., Burgess, A., Cavanaught, D. (2009). Clustering of Internet risk behaviors in a middle school student population. School Health, vol. 79, no. 11: 547-553.

Greenhow, C., Walker, J. D., Kim, S. (2009). Millennial Learners and Net-Savvy Teens? Examining Internet Use among Low-Income Students. Journal of Computing in Teacher Education, vol. 26, no. 2: 63-68.

Guan, S., Subrahmanyam, K. (2009). Youth Internet use: risks and opportunities. Current Opinion in Psychiatry, no. 22: 351-356.

Eldeleklioglu, J. (2008). Gender, Romantic Relationships, Internet Use, Perceived Social Support and Social Skills as the Predictors of Loneliness. Eurasian Journal of Educational Research, no. 33: 127-140.

EU Kids Online II: European Children's Use, Risk and Safety Online. (2010). Prieiga internete: http://www2.lse. ac.uk/media@1se/research/EUKidsOnline/Home.aspx [žiūrèta 2013-01-14].

Jessor, R. (1991). Risk Behavior in Adolescence: a Psychosocial Framework for Understanding and Action. Journal of Adolescent Health, no. 12: 597-605.

Kolpakova, O., Liubimova, A., Levina, O. (2012). Understanding risky online behavior of 14-17 years old Russian children. Prieiga internete: http://www.childcentre.info/robert/public/Kolpakova.pdf [žiūrèta 2013-06-14]. 
Livingstone, S., Ólafsson, K. (2011). Risky communication online. EU Kids Online, EU Kids Online Network, London, UK.

Livingstone, S., Helsper, E. (2008). Parental mediation and children's internet use. Journal of broadcasting \& electronic media, vol. 52, no. 2: 581-599.

Lekavičienè, R., Vasiliauskaitė, Z., Antinienė, D. ir kt. (2010). Bendravimo psichologija. Vilnius: Alma littera.

Lenhart, A. (2009). Teens and Social Media. Prieiga internete: http://isites.harvard.edu/fs/docs/icb.topic786630. files/Teens\%20Social\%20Media\%20and\%20Health\%20-\%20NYPH\%20Dept\%20Pew\%20Internet.pdf

Mesch, G. S. (2003). Social Relationships and Internet Use among Adolescents in Israel. Social Science Quarterly, vol. 82, no. 2: 329-340.

Milne, G. R., Lauren I. ir kt. (2009). Toward an Understanding of the Online Consumer's Risky Behavior and Protection Practices. Journal of Consumer Affairs, vol. 43 (3): 452-476.

Noll, J. G., Chad, E., Barnes, J. E. (2013). Association of Maltreatment With High-Risk Internet Behaviors and Offline Encounters. Pediatrics, no. 10: 510-517.

Park, S. K., Kim, A. Y., Cho, C. B. (2008). Prevalence of Internet Addiction and Correlations with family Factors Among South Korean Adolescents. Adolescence, vol. 43, no. 172: 895-909.

Pociūtė, B., Krancaitė, E. (2012). Paauglių aktyvumas vs. pasyvumas interneto socialiniame tinkle „facebook“ ir sąsajos su jaučiamu vienišumu bei asmenybės bruožais. Psichologija, nr. 8: 46-79.

Ruškus, J., Sujeta, I. (2011). Moksleivių vaikinų sąmoningumo ugdymas reflektuojant internetinę pornografiją. Acta paedagogica Vilnensia, p. 82-95.

Ruškus, J., Žvirdauskas, D., Kačenauskaitė, V., Žvirdauskienė R. (2009). Paaugliu elgsena elektroninèje erdvejje. Tyrimo atsakaita: LR S̆MM.

Šeibokaitè, L. (2008). Save ir kitus žalojančio elgesio kitimai nuo 5 iki 12 klasès ir su šiuo elgesiu susije psichosocialiniai veiksniai. Daktaro disertacija. Kaunas: VDU leidykla.

Umbrasienè, N., Narskauskaitė, L. (2010). Psichosocialiniai veiksniai, lemiantys vaikų rizikingą elgesi. Visuomenés sveikata, nr. 3(50): 24-29.

Pilkauskaitė-Valickienė, R., Raižienė, S., Žukauskienė, R. (2009). Elektroninių patyčių paplitimas tarp Klaipėdos apskrities vyresniujų klasių moksleivių. Socialinis darbas, nr. 8(2): 114-121.

Wang, R., Bianchi, S. M., Raley, S. B. (2005). Teenagers' Internet Use and Family Rules: A Research Note. Journal of Marriage and Family, vol. 10, no. 67: 1249-1258.

Wells, M. (2006). Internet-Related Problems Coming to the Attention of School Social Workers. Children \& School, vol. 28, no. 4: 237-242.

Wells, M., Mitchell, K. J. (2008). How Do High-Risk Youth Use the Internet? Characteristics and Implications for Prevention. Child Maltread OnlineFirst, vol. 20, no. 10: 1-8.

Zaleckienè, I. (2003). Paauglių gebèjimai suvokti informaciją. Žiniasklaida ir asmenybès raida: nepilnamečiu apsauga ir žmogaus orumas. Tarptautinès konferencijos pranešimas.

Žibeniene, G., Brasienè, D. (2013). Naudojimasis internetu, internetiniais socialiniais tinklais ir galimai patiriamos grèsmès: mokinių nuomonè. Socialinès technologijos, nr. 3(1): 53-67.

Žukauskienè, R. (2012). Raidos psichologija: integruotas požiūris. Vilnius: Margi raštai.

Žukauskienė, R. (2007). Raidos psichologija. Vilnius: Margi raštai.

\section{FACTORS OF TEENAGER'S RISKY ONLINE BEHAVIOUR}

\section{Rasa Jokubaitė}

\section{Summary}

Rapid development of information technologies determines the trend of increasing popularity of internet among teenagers, where social networks dominate. Teenagers' use of internet is expressed in different activities: surfing in information 
websites, internet games, exchange of video and other material, looking, listening and taking part in social websites. It is clear that the need for risk which is more intensive in teenage years, moves to web space in the age of technologies. Such behavior often causes various threats that can condition teenagers' vulnerability.

The relevance of the topic also reveals the fact that teenagers' online behavior is changing, it is becoming riskier and riskier. Teenagers often get in touch with strangers, visit violent and sexual websites, the popularity of electronic bullying is increasing among teenagers (EU Kids Online II, 2010; Ruskus, Zvirdauskas, Kacenauskaite, 2010; Pilkauskaite-Valickiene, Raiziene, Zukauskiene, 2009). Harassment and undesirable messages of sexual content, publication of personal information, sneering, identity thefts and others, often determine vulnerability of teenagers (Christofides, Muise, Desmarais, 2012; Barbovski, Marinescu, Velicu, 2011; Valcke, Wever, Keer, 2011; Bergman, Hutner, 2011; Livingstone, 2008).

Analysis of scientific literature revealed shortage of researches showing the ways of helping teenagers to handle threats in virtual space. Nevertheless, in order to discover ways of dealing with risky behavior of teenagers, firstly, on the basis of theoretical analysis, it is necessary to reveal factors determining teenagers' risky behavior.

Therefore, scientific issue of the research is formulated as a question: What factors determine teenagers' risky behavior on the internet?

Aim of the research - to reveal the peculiarities of expression of teenagers' risky behavior online.

Methods of the research: analysis of scientific literature that enabled to analyze and systemize scientific researches on the topic. Comparative analysis created opportunities to compare ideas of different authors, and results of scientific researches revealing the peculiarities of expression of teenagers' risky behavior online.

Although the popularity of the concept of risky behavior online in scientific works has been increasing over recent decades, there is still no overall concept of the term. Generally such behavior can be defined as potentially threatening online activity that poses threat on internet users.

Expression of risky behavior on the internet in point of teenagers is influenced by factors that encourage such kind of behavior and protect from them. After structuring the factors of risky behavior on the internet in regard to teenagers, internal and environmental factors which determine teenager behavior in the virtual space, can be distinguished. Internal factors, including the characteristics of adolescent years, personal features and behavioral problems, are analyzed under the individual level. Openness, neuroticism, loneliness, lack of self-confidence and communication difficulties, expressed in a fierce manner, encourage teenager's 
need to take a risk on the internet more often. Asocial behavior, rejection of social norms and values is also related to tendency to risky behavior in the virtual space.

According to R. Jessor (1991), environmental factors have a major influence on the expression of risky actions than internal ones. Individual is a part of the social environment, so its effect on teenager's behavior is also intense. As it was mentioned, environmental effect on the risky behavior online in point of teenagers is distinguished in 3 levels: family, peers and school. These are the aspects distinguished in the family level: psychological problems in a family (conflicts, violence, asocial behavior, the sense of insecurity), incomplete family structure and good circumstance. Teenagers who experience social isolation of peers, also those who feel misunderstood, unappreciated, lacking generous peer support, are more likely to take risky behavior on the internet. Negative influence of peers can also be a factor of the encouragement in point of risky actions on the internet. School level involves these factors: insecure school environment, low academic achievements, weak scholar-teacher contact, lack of self-realization opportunities, and lack of information about internet safety.

Internal factors that decrease risky behavior of teenagers on the internet include: high level of consciousness, strong value system, self-confidence, effective communication skills. Understanding, family support and appropriate education style are environmental factors that can decrease vulnerability of teenagers on the internet. Positive communication with friends, class friends, self-realization opportunities, high academic achievements, feeling of safety at school are also environmental protective actions that ensure safe behavior of teenagers on the internet space.

After the analysis of academic literature about the factors that determine risky behavior on the internet was performed, it was noticed that the factors of risky actions in regard to teenagers become exposed in a more extensive way in our country. However, there is little attention focused on the factors of such behavior on the internet. The exposure of conception regarding risky behavior on the internet and structuring the factors, which determine these actions, are especially important in the process of trying to solve the problem of teenagers' risky behavior online. This point is also important if we want to find methods that would be based in theory and verified in practice in terms of ensuring safety of teenagers in virtual space. 